Al-Azhar Bull. Sci. Vol. 20, No. 1 (June.): pp. 1-18, 2009.

\title{
ELECTROPHORESIS STUDY ON SERUM AND SOME TISSUES IN SUBSPECIES OF FAT SAND RAT PSAMMOMYS OBESUS IN EGYPT
}

\author{
MOHAMMAD I. BASUONY ${ }^{1}$; ZAKI T. ZAKI ${ }^{1}$; BOSHRA A. EL-SALKH ${ }^{2}$ AND \\ HANAA A.KHEDR ${ }^{2}$
}

Department of Zoology, Faculty of Science, Al-Azhar University for Girls ${ }^{2}$ and Boys $^{1}$, Nasr City, Cairo, Egypt

\begin{abstract}
Aim of the work: In the present study we revised the taxonomy of the mammalian species Fat Sand Rat Psammomys obesus inhabiting the Coastal Desert of Egypt by using protein separation to establishment the pervious taxonomy or not.

Material and methods: The study includes electrophoresis on serum, liver, kidney and muscle proteins of three subspecies of desert rodent Fat Sand Rat Psammomys obesus.

Results: The serum protein separation of subspecies terraesanctae and subspecies nicoli has the same number of proteins while in subspecies obesus has the small number of proteins. The liver protein separation of the investigated subspecies is different from each other in the number of proteins. The kidney protein separation of subspecies nicoli and subspecies obesus showed that the same number of proteins while subspecies terraesanctae has the smallest number of proteins. In the muscle of femur bone, the protein separation in subspecies nicoli, terraesanctae and obesus had the same number of proteins. As a result of the high similarity between subspecies obesus and terraescantae, must be collected in one subspecies called obesus and the third subspecies still as it nicoli.
\end{abstract}

Keywords: Electrophoresis, Fat Sand Rat, Psammomys obesus.

\section{Introduction}

The electrophoresis was initially used to describe the behaviour of electrically charged colloidal particles in an electric field. The migration of true solutes was originally referred to as onophoresis. Eventually, electrophoresis became the recognized term for the migration of all kinds of particles under the influence of an electric field (Laas, 1998).

Proteins are large molecules varying in molecular weight from 1 to $1000 \mathrm{kDa}$ (Kilodalton) and containing a linear sequence of amino acids covalently linked by peptide bonds (Harrison and Levitt, 1987). Proteins are present in all body fluids, but they are the proteins circulating in the blood that are readily accessible and can be analyzed directly (Fountoulakis et al., 1998). 
Sodium Dodecyle Sulphate Polyacrylamide Gel Electrophoresis (SDS-PAGE) still considered as the reference method for the detection of differences at the protein pattern being depend on the molecular weight of the separated proteins (Janson, 1998). It also can be a useful tool for monitoring patients over long periods of time when there are marked alterations in the levels of particular proteins (Jenkins and Guerin, 1997; Crocker and Burnett, 1998).

The success of electrophoresis in separating serum proteins into different fractions results from the heterogenity of charges of these molecules. Analysis of mixture of proteins to determine the number of molecular weight of different polypeptide chain is now almost exclusively carried out using polyacrylamide gel electrophoresis PAGE (Luzio and Thompson, 1990). Also they added that gels either cast in glass tubes (tube gels) or more commonly cast between two glass plates (slab gels).

Polyacrylamide is a polymer which can be poured as a liquid, after pouring, and with the appropriate added catalysts, it sets to a clear flexible, solid support in which electrophoresis of proteins can be carried out (Luzio and Thompson, 1990). Polyacrylamide gels are formed by co-polymerization of acrylamide monomer, $\mathrm{CH}_{2}=\mathrm{CH}-\mathrm{CO}-\mathrm{NH}_{2}$ in the presence of smaller amounts of $\mathrm{N}, \mathrm{N}$-methylene bisacrylamide which is used as a cross-linking agent, a catalyst, ammonium persulfate and an accelerator, tetramethylene diamine (TEMED) which decompose the persulfate ion to give a free radical. The mechanism of gel formation is free radical vinyl addition (Andrews, 1986). The proteins in Polyacrylamide Gel Electrophoresis (PAGE) migrate in response to the electrical field through the pores in the gel matrix. The porosity of gels is easily adjusted by changing the composition of acrylamide perior to polymerization, where pore size decreases with higher acrylamide concentrations. The combination of gel pore size, protein charge and shape determines the migration rate of the protein (Gallagher and Leonard, 1987).

Electrophoresis analysis was used to determine the differences between protein fractions and enzymatic secretion in both Barbus bynii and Bagrus docmac (Zaki et al., 1995). Also Miguel and Pobles (1993) used polyacrylamide gel electrophoresis in purification of specific protein from the liver of rainbow trout (Salmo gairdneri). On the other side Karasinski (1993) declared that electrophoretic analysis of muscle 


\section{ELECTROPHORESIS STUDY ON SERUM AND SOME}

myosine revealed a large variety among species in myosin isoform composition.

Tasi and Yang (1975) concluded that the electrophoretic patteren were consistant with several of body weight, size, sexes or fishing localities, but the electropherograms showed species specific pattern. Assessment of different effects of chemicals in the animal body was carried out using on electrophoretic method.

Gun and Colak (2004) stated that estrase enzymes from 30 species of Arvicola terrestris in four localities in Krflehir provience are examined using starch gel electrophoresis and blood serum proteins from 27 speciemens using SDS-PAGE. It is determined that there is a variation in the globulin, prealbumin and postalbumen regions while the albumin region is monomorphic. Nonspecific estrases in the muscle, heart, kidney, and liver tissues of rats (Rattus norvigicus) are examined by horizontal starch gel electrophoresis. These findings showed that nonspecific esterases are very polymorphic (Verimli et al., 2000). Blood serum electrophoresis of Tamias dorsalis compared to other species of Tamias indicated that Tamias dorsalis varies from all (Blake, 1992).

In the present study we revised the taxonomy of the mammalian species Fat Sand Rat Psammomys obesus inhabiting the Coastal Desert of Egypt by using protein separation to establishment the pervious taxonomy or change it.

\section{Material and Methods}

Fat Sand Rat Psammomys obesus has three subspecies in Egyptian deserts; obesus inhabits Coastal Western Desert, nicoli in north Eastern Desert and terraesanctae in North Sinai. These rodents collected from natural habitats, weighed and transferred alive to the laboratory in separate cages before classification according to Osborn and Helmy (1980).

For the electrophoretic studies, the samples were taken from different tissues of the rodent specimens. Serum, liver, kidney and muscles are the tissues taken from the specimens for electrophoresis study. The solutions for the gel are:

\section{Stock solution (1)}

Acrylamide / bis (30 \%): 30 grams of acrylamide and 0.8 grams of N, Nmethyleen bisacrylamide (BDH) were dissolved in $100 \mathrm{ml}$ distilled water. The solution was filtered and stored in a dark bottle at $4 \mathrm{C}^{\circ}$ till used.

Stock solution (2) 
Stocking buffer: Tris - $\mathrm{HCl}$ solution (PH 6.6) was prepared by dissolving 9.0 grams Tris-hydroxymethylaminomethan in $100 \mathrm{ml}$ distilled water. The $\mathrm{PH}$ was adjusted using $1 \mathrm{~N}$ Hydrochloric acid $(\mathrm{HCl})$ or $1 \mathrm{M}$ Sodium hydroxide $(\mathrm{NaOH})$ then was stored at $4^{\circ} \mathrm{C}$.

Stock solution (3)

Separating buffer: Tris- Hcl solution (PH 8.8) was prepared by dissolving 27.3 grams Tris-hydroxymethylaminomethane in $100 \mathrm{ml}$ distilled water and about $20 \mathrm{ml}$ $2 \mathrm{~N} \mathrm{Hcl}$ were added until the optimum $\mathrm{PH}$, then the solution was stored at $4{ }^{\circ} \mathrm{C}$

\section{Stock solution (4)}

Running buffer: 15.0 grams Tris - base, 72.0 grams glycine and 5.0 grams sodium dodecyl sulfate (SDS) were dissolved in $5 \mathrm{~L}$. distilled water and adjusted to PH 8.3 with $1 \mathrm{~N} \mathrm{Hcl}$ then stored at $4^{\circ} \mathrm{C}$.

\section{Stock solution ( 5 )}

Sample buffer:

Tris - borate solution PH 8.2 was prepared by dissolving 3.25 grams tris- base and 3.66 grams boric acid in $100 \mathrm{ml}$ distilled water, $\mathrm{PH}$ was adjusted with $1 \mathrm{~N} \mathrm{Hcl}$. The solution was filtered and stored at $4^{\circ} \mathrm{C}$

\section{Stock solution (6)}

10 \% SDS solution: dissolving 10.0 gm sodium dodecyl sulfate in a small amount of water with gentle stirring and thin distilled water was added to $100 \mathrm{ml}$. Procedure

A set of two glass plates of $4 \mathrm{~mm}$ thickness was used for gel $1 \mathrm{~mm}$. Thickness with a total $14 \times 16 \mathrm{~cm}$ area; $11 \mathrm{~cm}$, separating plus $3 \mathrm{~cm}$ stocking gels. OWL vertical slab was used in protein separation. The separating and stocking Gels were prepared according to Table (1).

\section{Table 1: The separating and stocking gels.}


ELECTROPHORESIS STUDY ON SERUM AND SOME

\begin{tabular}{|l|c|c|}
\hline \multicolumn{1}{|c|}{ Solutions } & Separating gel & Stocking gel \\
\hline Acrylamide (30 \%) & $12 \mathrm{ml}$ & $3 \mathrm{ml}$ \\
\hline Tris-HCl buffer (PH 8.8) & $6 \mathrm{ml}$ & ------ \\
\hline Tris-HCl buffer (PH 6.6) & ------ & $3 \mathrm{ml}$ \\
\hline Distilled water & $10 \mathrm{ml}$ & $12 \mathrm{ml}$ \\
\hline Glycerol & $4 \mathrm{ml}$ & ------ \\
\hline SDS (10 \%) & $300 \mathrm{ul}$ & $150 \mathrm{ul}$ \\
\hline TEMED & $30 \mathrm{ul}$ & $15 \mathrm{ul}$ \\
\hline Ammonium persulphate (10\%) & $150 \mathrm{ul}$ & $75 \mathrm{ul}$ \\
\hline Total volume & $32.48 \mathrm{ml}$ & 18.24 \\
\hline
\end{tabular}

Separating gel was poured between the glass plates immediately after adding ammonium persulfate (APS). After polymerization of the separating gel, stocking gel was poured into the glass plates space and then the comb was inserted to form sample wells.

\section{Sample preparation}

According to Stegemman et al. (1988), the blood serum sample were diluted 1 : 3 with sample buffer then put in a boiling water path for 5 minutes. The samples were then applied to the gel wells (after cooling to the room temperature). For muscle protein (400 ul sample $+100 \mathrm{ul} \mathrm{SDS}$ and $50 \mathrm{ul}$ mercbtoethanol). The samples were applied to the gel wells.

\section{Running condition}

The runs were carried out with a constants volt of 200 volt. When the tracking dye becomes one $\mathrm{cm}$ behind the end of the gel.

\section{Staining}

The separated proteins were stained with coomassie brilliant blue stain R- 250, which had been prepared as follows:

Coomassie brilliant blue $\mathrm{R}-2500$. 1gm

Dist. Water

Acetic acid

Methanol

Trichloroacetic acid bands. 


\section{Destaining}

After gel staining, the gel was transferred to destaining solution to remove the excess stain, till the clearance of the background.

Destaining solution

$\begin{array}{ll}\text { Methanol } & 150 \mathrm{ml} \\ \text { Acetic acid } & 50 \mathrm{ml} \\ \text { Dist. Water } & 300 \mathrm{ml}\end{array}$

The slab gel of proteins were photographed analysis percentages of the peaks of each line was carried out using Hoofer scanning densitometer GS 300. Sigma protein marker wide range (MW 6.500-205.000) was used to determinate the approximate molecular weight of protein fractions.

The obtained results were analyzed statistically according to the method of Sendcor (1956) and the data obtained from the gel scanning were analyzed using the computer corresponding software, gel scan Vergin 5.1.

\section{Results}

\section{Serum protein pattern}

Scanning of SDS - PAGE gel of blood serum proteins in three subspecies of Psammomys obesus revealed the presence of thirteen types in serum of Psammomys obesus nicoli and Psammomys obesus terraesanctae. The molecular weights of which are ranged from 229 to $11 \mathrm{KDa}$ in Psammomys obesus nicoli and in Psammomys obesus terraesanctae they are ranged from and 223 to $28 \mathrm{KDa}$. The segregation of serum protein in Psammomys obesus obesus revealed the presence of twelve types of protein with molecular weights ranged from 179 to 27 KDa which was smaller than that in the other subspecies.

The area percent of Psammomys obesus nicoli ranged approximately from 2.04\% to $7.16 \%$, whereas, the area percent of Psammomys obesus terraesanctae is smaller where it ranged from $1.31 \%$ to $14.38 \%$. The area percent of Psammomys obesus obesus is greater than that in Psammomys obesus nicoli and Psammomys obesus terraesanctae which ranged from $6.18 \%$ to $19.96 \%$ (Table 2 and Figure 1)

Table (2): The results of SDS gel scanning of the serum of Psammomys obesus nicoli, $P . o$. Obesus and P. o. terraesanctae 
ELECTROPHORESIS STUDY ON SERUM AND SOME

7

\begin{tabular}{|c|c|c|c|c|c|c|c|c|}
\hline \multicolumn{3}{|c|}{ P. o. nicoli } & \multicolumn{3}{c|}{ P. obesus } & \multicolumn{3}{c|}{ P. o. terraesanctae } \\
\hline $\boldsymbol{P K}$ & $\begin{array}{c}\text { MW } \\
(\text { KDa })\end{array}$ & Amt \% & PK & $\begin{array}{c}\text { MW } \\
(\text { Kd })\end{array}$ & Amt \% & PK & $\begin{array}{c}\text { MW } \\
(\text { KDa })\end{array}$ & Amt \% \\
\hline 1 & 229 & 2.04 & 1 & 179 & 6.18 & 1 & 223 & 1.31 \\
\hline 2 & 213 & 7.41 & 2 & 162 & 1.06 & 2 & 177 & 1.57 \\
\hline 3 & 172 & 6.64 & 3 & 140 & 7.79 & 3 & 161 & 1.07 \\
\hline 4 & 157 & 5.31 & 4 & 119 & 2.49 & 4 & 140 & 3.17 \\
\hline 5 & 133 & 6.64 & 5 & 100 & 1.32 & 5 & 119 & 7.76 \\
\hline 6 & 119 & 1.55 & 6 & 78 & 23.17 & 6 & 103 & 2.96 \\
\hline 7 & 102 & 7.35 & 7 & 48 & 24.06 & 7 & 79 & 10.45 \\
\hline 8 & 75 & 17.52 & 8 & 40 & 2.36 & 8 & 50 & 20.78 \\
\hline 9 & 46 & 5.87 & 9 & 34 & 6.12 & 9 & 47 & 6.82 \\
\hline 10 & 39 & 7.91 & 10 & 32 & 4.56 & 10 & 42 & 16.25 \\
\hline 11 & 33 & 13.88 & 11 & 30 & 0.76 & 11 & 34 & 9.35 \\
\hline 12 & 26 & 10.73 & 12 & 27 & 19.96 & 12 & 32 & 4.14 \\
\hline 13 & 11 & 7.16 & & & & 13 & 28 & 14.38 \\
\hline
\end{tabular}

The examination of similarity coeffecient of serum protein separation between the three studied subspecies is represented as $82.31 \%$, however, the similarity coeffecient between Psammomys obesus obesus and Psammomys obesus terraesanctae represents as $88 \%$ (Figure 2).

Liver protein pattern

The liver protein separation showed eleven types of protein in Psammomys obesus terraesanctae and Psammomys obesus obesus while in Psammomys obesus nicoli, the liver protein separation showed only eight types of proteins. The molecular weights of these proteins ranged from 207 to $14 \mathrm{KDa}$ in Psammomys obesus nicoli while in Psammomys obesus terraesanctae and Pammomys obesus obesus they are ranged from 208 to $13 \mathrm{KDa}$ and 209 to $5 \mathrm{KDa}$ respectively. The molecular weights of proteins of Psammomys obesus obesus are greater than that in the other subspecies. 


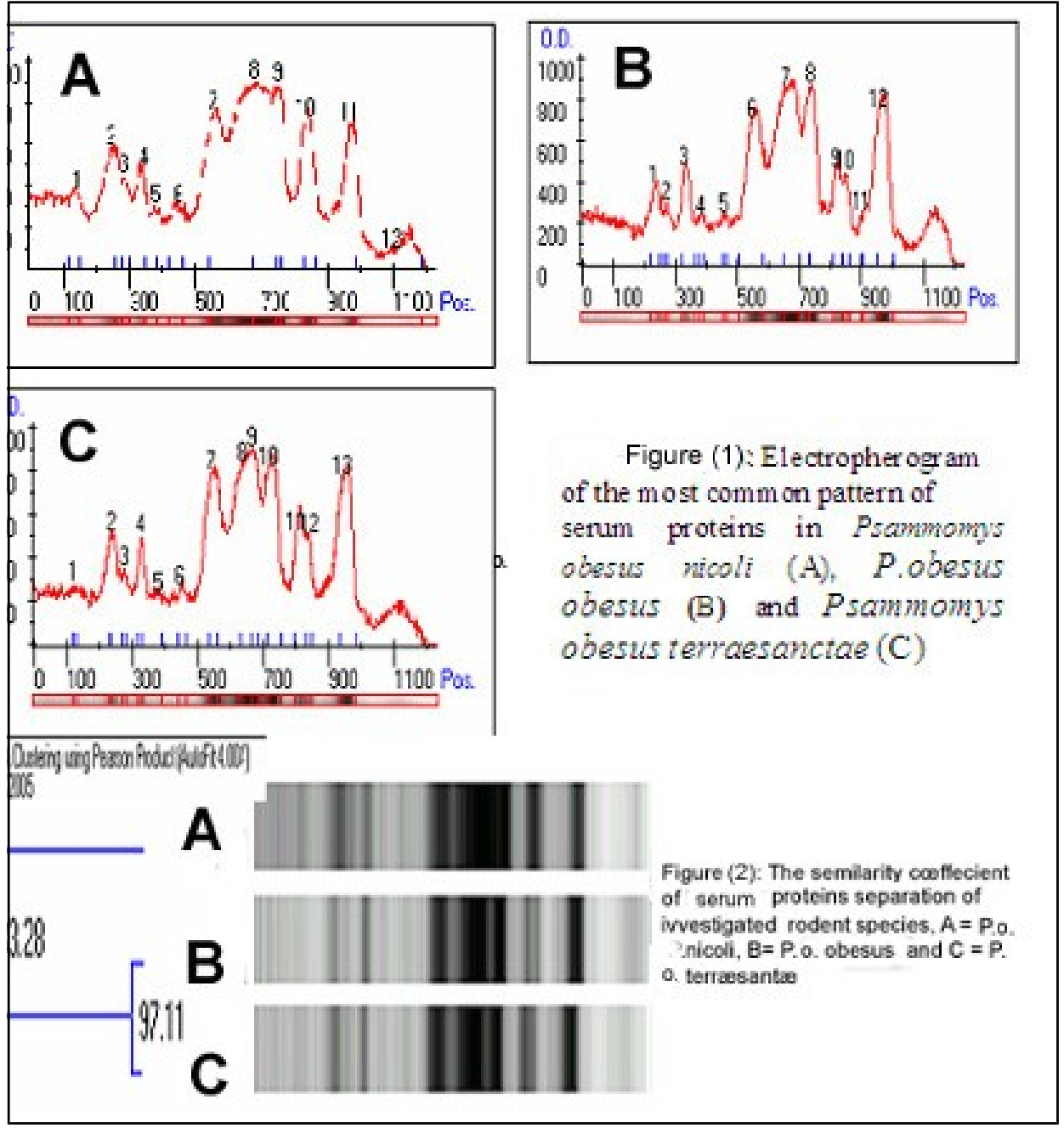

The area percent of Psammomys obesus terraesanctae and Psammomys obesus obesus ranged approximately from $1.88 \%$ to $26.4 \%$ and $3.14 \%$ to $26.81 \%$ respectively while in Psammomys obesus nicoli, ranged from $3.22 \%$ to $23.81 \%$ (Table 3 and Figure 3).

The examination of similarity coeffecient of protein separation between Psammomys obesus terraesanctae and Psammomys obesus obesus is represented 93.69\%, while the similarity coeffecient of liver protein separation between Psammomys obesus nicoli, Psammomys obesus terraesanctae and Psammomys obesus obesus is represnted as $58.25 \%$ (Figure 4). 
ELECTROPHORESIS STUDY ON SERUM AND SOME

Table (3): The results of SDS gel scanning of the liver of Psammomys obesus nicoli, $P$. $o$. Obesus and P. o. terraesanctae

\begin{tabular}{|c|c|c|c|c|c|c|c|c|}
\hline \multicolumn{3}{|c|}{ P. o. nicoli } & \multicolumn{3}{c|}{ P. o. obesus } & \multicolumn{3}{c|}{ P. o. terraesanctae } \\
\hline PK & $\begin{array}{c}\text { MW } \\
\text { (KDa) }\end{array}$ & Amt \% & PK & $\begin{array}{c}\text { MW } \\
(\text { Kd })\end{array}$ & Amt \% & PK & $\begin{array}{c}\text { MW } \\
(\text { KDa })\end{array}$ & Amt \% \\
\hline 1 & 207 & 7.76 & 1 & 209 & 4.22 & 1 & 208 & 4.76 \\
\hline 2 & 52 & 17.50 & 2 & 67 & 3.14 & 2 & 120 & 5.92 \\
\hline 3 & 42 & 18.11 & 3 & 52 & 6.79 & 3 & 68 & 3.54 \\
\hline 4 & 33 & 16.60 & 4 & 46 & 15.07 & 4 & 62 & 3.56 \\
\hline 5 & 30 & 23.81 & 5 & 42 & 5.88 & 5 & 52 & 5.42 \\
\hline 6 & 26 & 5.37 & 6 & 33 & 6.53 & 6 & 41 & 1.88 \\
\hline 7 & 22 & 3.22 & 7 & 31 & 5.23 & 7 & 34 & 8.19 \\
\hline 8 & 14 & 7.63 & 8 & 26 & 4.48 & 8 & 31 & 26.48 \\
\hline & & & 9 & 23 & 12.75 & 9 & 38 & 25.79 \\
\hline & & & 10 & 12 & 26.81 & 10 & 22 & 11.52 \\
\hline & & & 11 & 5 & 9.11 & 11 & 13 & 2.94 \\
\hline
\end{tabular}


Figure (3): Electrophtrogram of the most oummon pattern of muscle protein in Psammonns obests nicoit (A), P.O. obesus(B)and Psommoms obesus terraesanctae (C)

Figure (4): The semilarity conffecient of liver proteins separation of ivvestigated rodent species, $\mathrm{A}=\mathrm{P}$.o. 'nicoli, $\mathrm{B}=\mathrm{P}$. O. obesus and $\mathrm{C}=\mathrm{P}$. o. terrasantwe 
Protein patteren of kidneys

Scanning of SDS-PAGE gel of kidney proteins in Psammomys obesus nicoli and Psammomys obesus obesus had ten types of proteins which are similar to each other. The kidney protein separation in Psammomys obesus terraesanctae showed seven types of proteins which are different from the other subspecies. The molecular weight of these proteins in Psammomys obesus nicoli is ranged from 66 to $11 \mathrm{KDa}$. The molecular weight of proteins in Psammomys obesus terraesanctae and Psammomys obesus obesus ranged from 76 to $11 \mathrm{KDa}$ and 69 to 6 KDa respectively (Table 4 and Figure 5).

The area percent of Psammomys obesus nicoli, Psammomys obesus terraesanctae and Psammomys obesus obesus are ranged from $0.72 \%$ to $11.34 \%$, $4.30 \%$ to $12.98 \%$ and $2.34 \%$ to $40.40 \%$ respectively. The area percent of Psammomys obesus terraesanctae is greater than that in the other subspecies.

The examination of similarity coeffecient of protein separation between Psammomys obesus terraesanctae and Psammomys obesus obesus is represented 97.22\%, while the similarity coeffecient of kidney protein separation between Psammomys obesus nicoli, Psammomys obesus terraesanctae and Psammomys obesus obesus is represnted as $90.32 \%$. However, the similarity coeffecient between Psammomys obesus terraesanctae, Psammomys obesus obesus and Psammomys obesus nicoli is represented as $94.26 \%$ (Figure 6).

Protein patteren of muscles

Scanning of SDS-PAGE gel of muscle proteins in femur bone of Psammomys obesus nicoli, Psammomys obesus terraesanctae and Psammomys obesus obesus showed nine types of proteins. The molecular weight of these proteins in Psammomys obesus nicoli, Psammomys obesus terraesanctae and Psammomys obesus obesus ranged from 96 to $23 \mathrm{KDa}, 74$ to $24 \mathrm{KDa}$ and 70 to $25 \mathrm{KDa}$ respectively. The molecular weight of protein of Psammomys obesus nicoli is greater than that in the other subspecies.

The percentages area of Psammomys obesus nicoli, Psammomys obesus terraescantae and Psammomys obesus obesus ranged from $1.36 \%$ to $23.33 \%, 0.16$ $\%$ to $23.32 \%$ and $1.48 \%$ to $38.31 \%$ respectively (Table 5 and Figure 7 ). 
ELECTROPHORESIS STUDY ON SERUM AND SOME

Table (4): The results of SDS gel scanning of the kidney of Psammomys obesus nicoli, $P$. o. obesus and P. o. terraesanctae

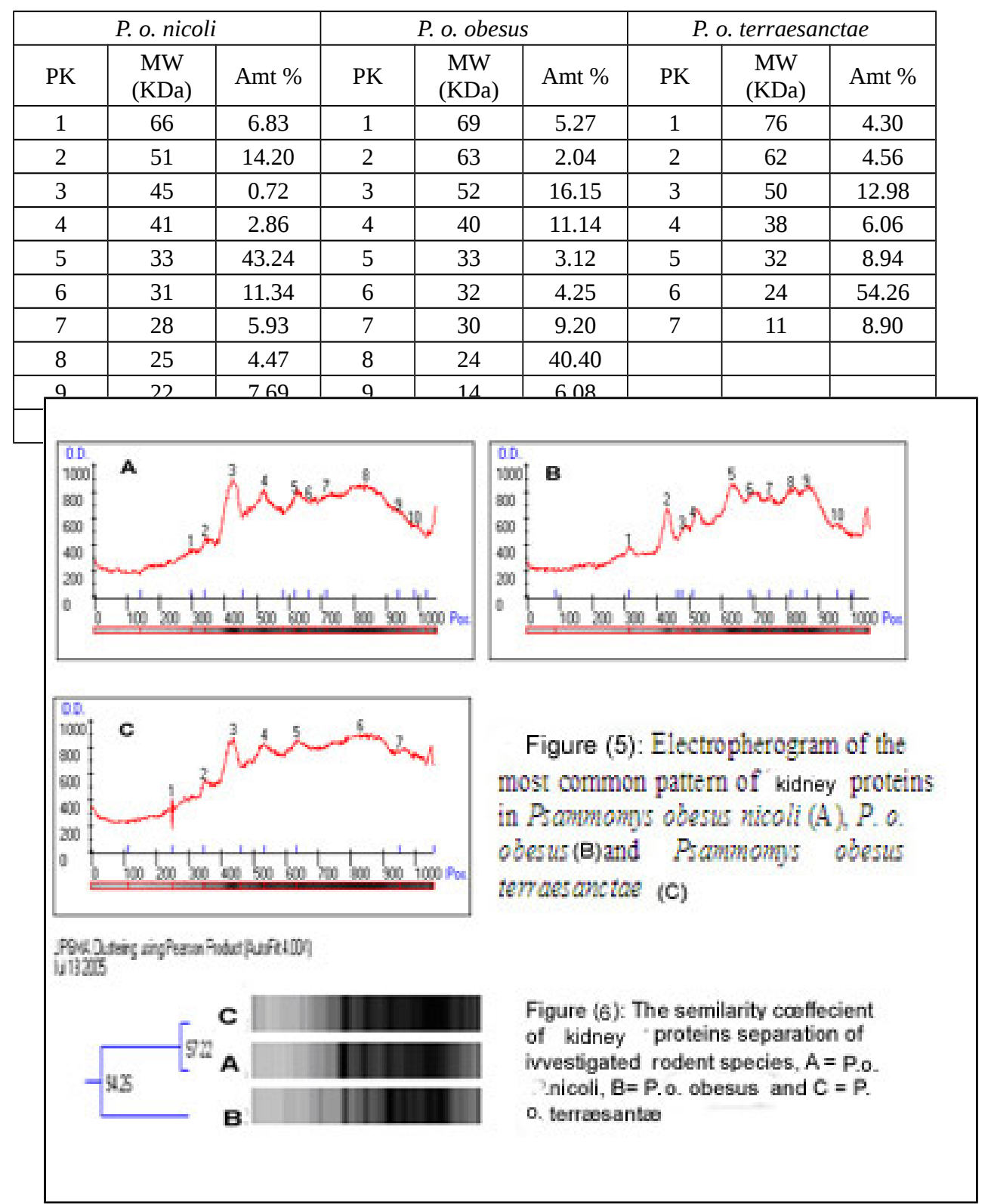


Table (5): The results of SDS gel scanning of the muscles of Psammomys obesus nicoli, $P$. o. obesus and $P$. o. terraesanctae

\begin{tabular}{|l|l|l|c|c|c|c|c|c|}
\hline \multicolumn{3}{|c|}{ P. o. nicoli } & \multicolumn{3}{c|}{ P. o. obesus } & \multicolumn{3}{c|}{ P. o. terraesanctae } \\
\hline \multicolumn{1}{|c|}{ PK } & MW (KDa) & Amt \% & PK & $\begin{array}{c}\text { MW } \\
\text { (KDa) }\end{array}$ & Amt \% & PK & $\begin{array}{c}\text { MW } \\
\text { (KDa) }\end{array}$ & Amt \% \\
\hline 1 & 69 & 11.28 & 1 & 70 & 3.90 & 1 & 74 & 0.16 \\
\hline 2 & 53 & 23.33 & 2 & 54 & 17 & 2 & 54 & 23.22 \\
\hline 3 & 44 & 1.36 & 3 & 45 & 1.53 & 3 & 44 & 1.72 \\
\hline 4 & 37 & 4.39 & 4 & 38 & 4.57 & 4 & 37 & 5.36 \\
\hline 5 & 34 & 16.95 & 5 & 34 & 17.18 & 5 & 34 & 22.43 \\
\hline 6 & 31 & 14.29 & 6 & 32 & 2.34 & 6 & 31 & 14.24 \\
\hline 7 & 30 & 5.26 & 7 & 30 & 1.48 & 7 & 30 & 6.21 \\
\hline 8 & 27 & 7.72 & 8 & 27 & 38.31 & 8 & 27 & 3.34 \\
\hline 9 & 23 & 15.42 & 9 & 25 & 13.70 & 9 & 24 & 23.32 \\
\hline
\end{tabular}

The examination of similarity coeffecient of muscle protein separation between Psammomys obesus terraesanctae, Psammomys obesus nicoli and Psammomys obesus obesus is represented as $77.75 \%$, while the similarity coeffecient of muscle protein separation between Psammomys obesus nicoli and Psammomys obesus terraesanctae is represented as $96.43 \%$. However, the similarity coeffecient of muscle protein separation between Psammomys obesus terraesanctae, Psammomys obesus nicoli and Psammomys obesus obesus is represented as 94.92\% (Figure 8).

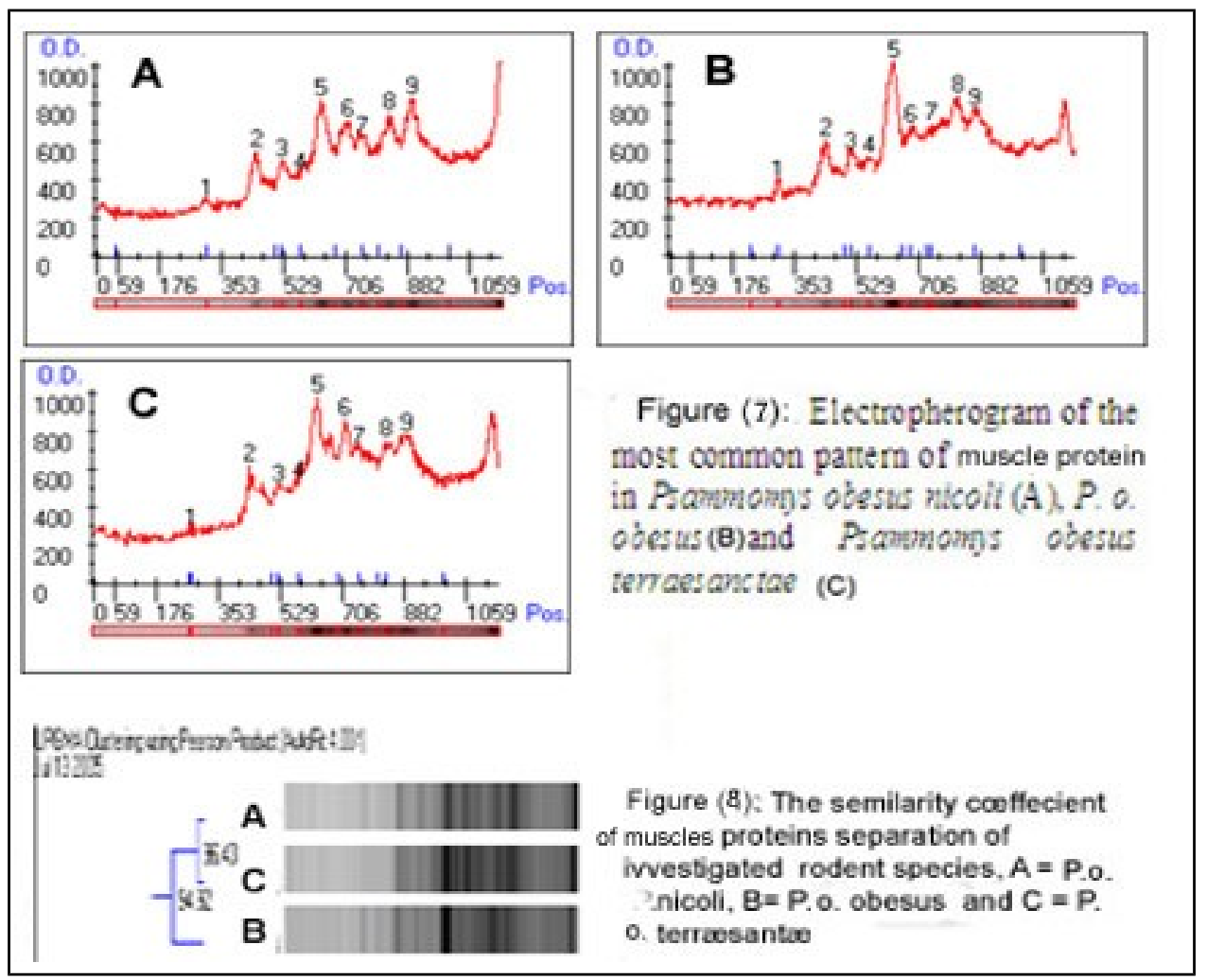




\section{Discussion}

Electrophoresis of serum and tissue (liver, kidney and muscle) protein separations of three subspecies of Psammomys obesus which were collected from Western, Eastern and Sinai Desert namely, obesus, nicoli and terraesanctae respectively. These are thirteen types of protein in serum of Psammomys obesus terraesanctae and Psammomys obesus nicoli while in Psammomys obesus obesus it showed twelve types of proteins. Similar observations were recorded in speciemens collected from different localities of Turkey (Verimli et al., 2000) in Arvicola terrestris (Colak, 2004) in Tamias dorsalis (Blake, 1992) in Apodemus flavicollis and Apodemus hermonesis (Verimli et al., 2001) in Dryomys nitedula and Dryomys laniger (Yigit et al., 2003).

The liver protein separation of Psammomys obesus terraesanctae and Psammomys obesus obesus showed eleven types of proteins while in Psammomys obesus nicoli showed eight types of proteins. Similar observations were recorded in estrase enzyme in the liver of Rattus norvigicus (Verimli et al., 2000).

The kidney protein separation of Psammomys obesus nicoli and Psammomys obesus obesus showed ten types of proteins while in Psammomys obesus terraesanctae showed seven and six protein types respectively. Similar observations were recorded in estrase in the kidney of Rattus norvigicus (Verimli et al., 2000).

Protein separation of muscle of femur bone in Psammomys obesus nicoli, Psammomys obesus terraesanctae and Psammomys obesus obesus had nine types of protein. Similar observation had been described in Rattus norvigicus (Verimli et al., 2000).

Table 6: Means of external and cranial measurements of Psammomys obesus subspecies (Osborn and Helmy, 1980). The numbers between parnesis represent the average numbers and the number after the parnesis is the number of measures animals.

\begin{tabular}{|l|l|l|l|}
\hline & $\begin{array}{l}\text { Psammomys obesus } \\
\text { obesus }\end{array}$ & $\begin{array}{l}\text { Psammomys obesus } \\
\text { nicoli }\end{array}$ & $\begin{array}{l}\text { Psammomys obesus } \\
\text { terraescantae }\end{array}$ \\
\hline HBL & $73(151-187) 168.4$ & $41(199-160) 178.6$ & $20(144-168) 157.5$ \\
\hline TL & $69(100-144) 125.4$ & $38(157-122) 143.5$ & $19(115-131) 122.8$ \\
\hline \%TL /HBL & $71(82.5-60.9) 73.5$ & $38(90.1-60.1) 80.2$ & $19(89.6-73.6) 78.0$ \\
\hline FL & $78(40-32) 36.9$ & $46(43-38) 40.2$ & $21(40-35) 36.8$ \\
\hline EL & $77(16-14) 14.8$ & $41(14-18) 16$ & $21(17-13) 14.6$ \\
\hline Wt & $37(205.1-116.3) 141.8$ & $27(223-106.6) 130$ & $12(135.3-92.1) 114.5$ \\
\hline ONL & $68(45.4-38.8) 41.7$ & $40(48.2-42.8) 45.4$ & $22(44.9-37.7) 41.0$ \\
\hline ZW & $59(27.4-23.7) 24.9$ & $31(28.8-25.4) 26.7$ & $18(26.6-22.2) 24.4$ \\
\hline NL & $67(17.6-14) 16.2$ & $38(20.9-17) 18.6$ & $21(18.5-15) 16.6$ \\
\hline
\end{tabular}

where: HBL: Head and body lengthy

TL: Tail length

FL: find foot length

EL : Ear length
$\mathrm{Wt}$ : body weigh ingans

ONL : occipitenasal length

ZW : zygomatic width.

NL : Nasal length 
This study revealed the similarity of proteins in serum, liver and kidney is very high between subspecies obesus and terraescantae inhabiting Western and Sinai Deserts respectively. The similarity is higher between subspecies obesus and terraescantae than that between each of them and the third subspecies nicoli. This observation is typical to that found by Osborn and Helmy (1980) on the external and cranial measurements of these subspecies (Table 6). However, the third subspecies nicoli inhabiting the northern region of Eastern Desert is somewhat different from the other two subspecies.

Psammomys obesus is one of the Saharo-Sindian species. This group of species occurs in the phytogeographic regions designated by Zohary (1973) as SaharoArabian and Irano-Turanian. Many of these species have Egypt as the center of this range and occur in the desert and subdesert regions extending from Mauritania to northwestern India (Qumsiyeh, 1985). The first population of Psammomys obesus appears to enter Africa from the east, following the end of the Saharan wet episodes, extending its range westwards along the Mediterranean seafront. The invasion of the Sahara by Psammomys obesus must have taken place prior to the evolution of the Neonile (Said, 1981), the Nile valley and delta then cut across the range of the species separating their eastern and western populations.

The subsequent breakdown of the Psammomys obesus populations into those of the Western Mediterranean Coastal Belt, the northern region of the Eastern Desert and the Sinai, is essentially a consequence of the development of the river Nile system. The delta and valley of the Neonile present a complete barrier that has completely separated the eastern and western populations of Psammomys obesus. Associated with the development of the river system is the extent of inundation of the Isthmus of Suez by the river water, which presents a barrier that seemed to the river water, which presented a barrier that seemed to block this Afro-Asian gateway. This barrier often partly separated the Eastern Desert and Sinai populations of this species (Nour El-Din, 2006). To the east of the Nile, in the northern part of Eastern desert, climatic barrier, to a lesser extent the lack of suitable habitats, and desertification seem to prevent the southward dispersion of Psammomys obesus and differentiation of the individuals of subspecies nicoli in this area.

So, as the high similarity in the proteins in the serum, liver, kidney and muscles between the two subspecies obesus and terraescantae must be collected in one subspecies called obesus and the third subspecies still as it nicoli. 


\section{References}

1. ANDREWS, A. T. (1986): Electrophoresis, Theory, Techniques and Biochemical Clinical Application. $2^{\text {nd }}$ ed. New York: Academic press, Pp. 161- 235.

2. BLAKE, H. E. (1992): Mammalian species. Tamias dorsalis. Amer. Soc. Mommal., (2): 1- 6

3. COLAK, R. (2004): An electrophoresis study on estrase and blood serum proteins of the water vole, Arvicola terrestris (L., 1758) (Mammalia: Rodentia). Turk J. Biol., 28: 47-53.

4. CROCKER, J. AND BURNETT, D. (1998): The science of laboratory and diagnosis. Isis Medical Media staff Ltd. Oxford: 455- 461.

5. FOUNTOULAKIS, M., JURANVILLE, JF., RODER, D., EVERS, S., PETER, B. AND LANGEN, H. (1998): Reference map of the low molecular mass proteins of Haemophilus influenzae. Electrophoresis, 19: 1819-1827.

6. GALLAGHER, S. R. AND LEONARD, R. T. (1987): Electrophoretic characterization of a detergent- treated plasma membrane fraction from corn roots. Plant Physio., 83: 265271

7. GUN, C. Y. AND COLAK, R. (2004): An electrophoretic study on estrase and blood serum proteins in the water vole, Arvicola terrestris (L.,1758) (Mammalia: Rodentia) in Krflehir provience. Turk. J. Biol., 28: 47- 53

8. HARRISON, H. H. AND LEVITT, M. H. (1987): Serum protein electrophoresis: principles, interpretations and practical considerations: Check sample (ASCP), 7: 1-16.

9. JANSON, J. C. (1998): Protein Purification, Principles, High Resolution Methods and Application. $2^{\text {nd }}$ ed.; John wiley and Sons Inc. New York and London, pp. 1-9

10. JENKINS, M. A. AND GUERIN, M. D. (1997): High resolution gel electrophoresis. J. Chromato. B., 699: 258-266

11. KARASINSKI, J. (1993): Diversity of native myosin and myosin heavy chain in fish skeletal muscles. Comp. Biochem. Physiol., 106B (4): 1041-047.

12. LAAS, T. (1998): Electrophoresis of gels. In "Proteins purification, principles, high resolution methods and aplication” $2^{\text {nd }}$ ed., John Wiley and sons. Inc. New York and London, Pp.: 450-463

13. LUZIO, J. P. AND THOMPSON, R. J. (1990): “Molecular Medical Biochemistry”. Cambridge Univ. Press - Cambridge. N. X.: 264

14. MIGUEL, J. L. AND POBLES, M. I. (1993): An electrophoretical study of ferritin from rainbow trout (Salmo gairdneri, R) Liver. Comp. Bioche. Physiol., 106 B (4): 937-942. 
15. NOUR EL-DIN, M. A. (2006): Ecological and taxonomic studies on some Egyptian reptilesof the genera Psammophis and Cerastes. Ph.D. thesis, Faculty of Science, Ain Shams University, Cairo, Egypt.

16. OSBORN, D. J. AND HELMY, I. (980): The contemporary land mammals of Egypt (including Sinai), Fieldiana Zool., 5: 1-59

17. QUMSIYEH, M. B. (1985): The Bats of Egypt. Texas Tech. Univ. Spec. Publ., 23:1-102.

18. SAID, R. (1981): The Geological Evolution of the River Nile. Springer-Verlag, New York.

19. SENDCOR, G. W. (1956): Statistical Methods. $5^{\text {th }}$ ed., Iow state Collage press, Ames., Iow, USA

20. STEGEMANN, H. BURGERMEISTER, W. SHAH, A. FRANCHSEN, H, AND KROGERRECKLEN-FROT, E. (1988): “Gel Electrophoresis between glass plates in polyacrylamide or other gels” Righetti / Vanoss / Vanderohoff eds., Elsevier (Amesterdam).

21. TASI, H. AND YANG, R. (1975): Electrograms of muscle extracts of tunas from the water around Taiwan. Acta Oceanogrphica Taiwanica, 5: 131-138

22. VERIMLI, R. YIGIT, N. COLAK, E. AND SÖZEN, M. (2000): Nonspecifiec estrase patteren of Rattus norvigicus (Berkenhout, 1769) in Western Turkey. Turk. J. Biol. 24: 825- 831

23. VERIMLI, R. YIGIT, N. COLAK, E. AND SÖZEN, M. (2001): Blood serum proteins of Apodemus flavicollis and Apodemus hermonensis (Mammalia: Rodentia) in Turkey. Turk J. Biol. 25: 89-92.

24. YIGIT, N. COLAK, E. COLAK, R. ÖZKAN, B. AND ÖZKURT, S. (2003): On the turkish populations of Dryomys nitedula (Pallas, 1779) and Dryomys laniger felten and storch, 1968 (Mammalia: Rodentia). Acta Zoologica Academiae Scientiarum Hungaricae, 49: 147-158.

25. ZAKI, Z, T. ABO-ZAID, M. M. IBRAHIM, I. G, AND BASUONY, M. I. (1995): Anatomical and biochemical studies of digestive mucosa of some fishes. Proc. Egypt. Acad. Sci., 45: 243-261.

26. ZOHARY, M. (1973): Geobotanical foundations of the Middle East. Verlag. Stuttgart. Germany, vol. 2, pp739. 


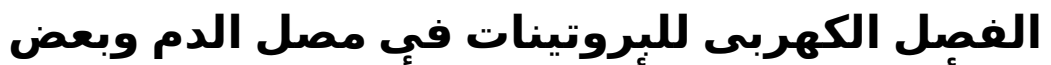





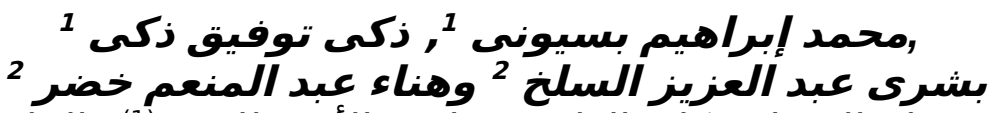
قسم علم الحيوان- كلية العلوم - جامعة الأزهر للبنين (1) والبنات (2)

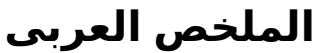

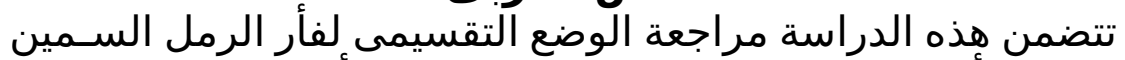

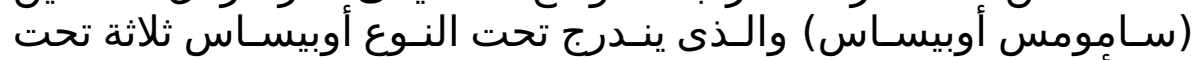

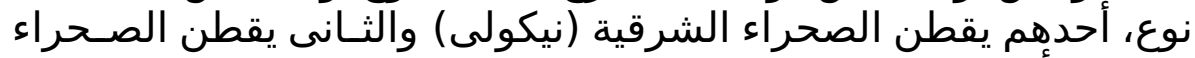



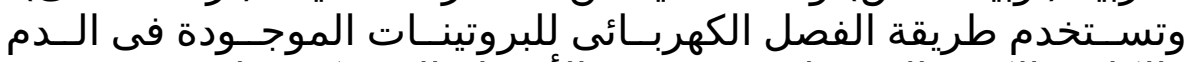

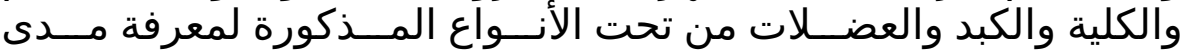

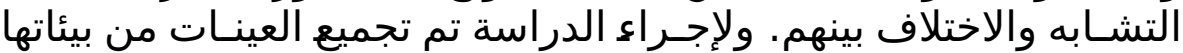

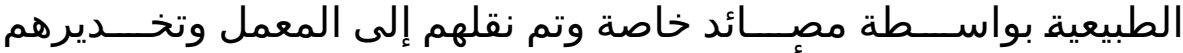
بمحلول إلكلوروفورم وأجريت عليهم الدراسات السابعة السابقة.



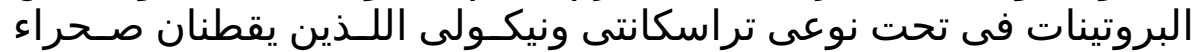

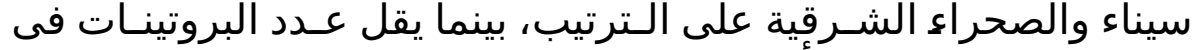

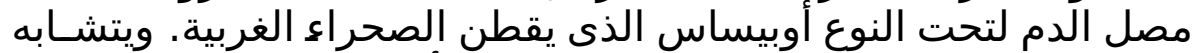

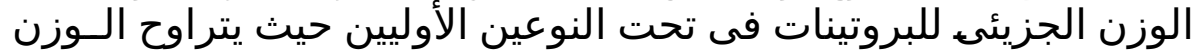

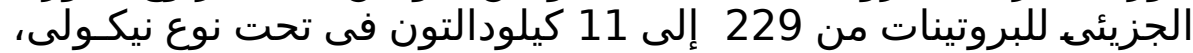

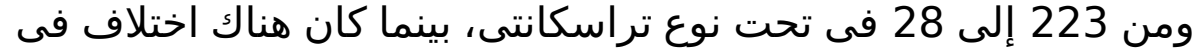

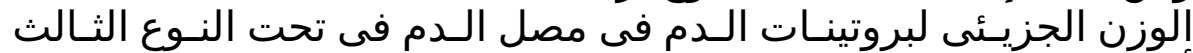

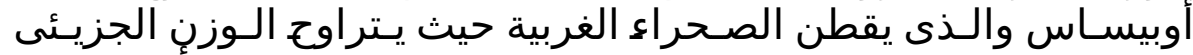

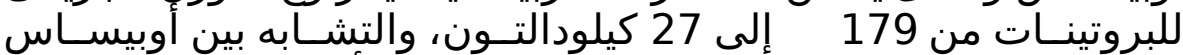



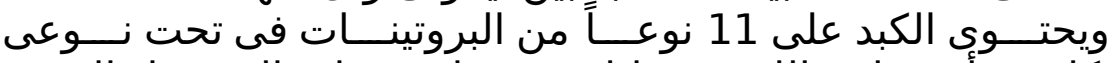

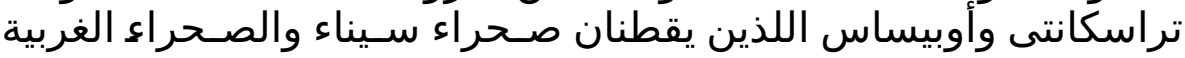

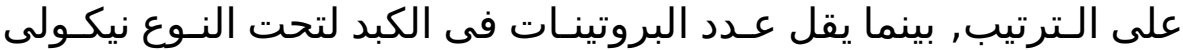

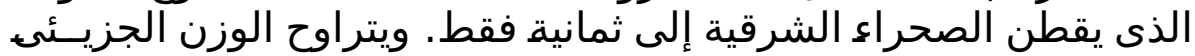

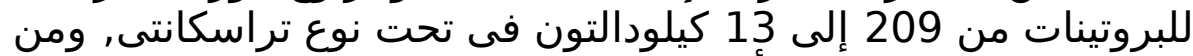
209 إلى 5 فى تحت نوع أوبيساس، وفيلوالون نيكولى يتراوح الوزن الجزيئى 




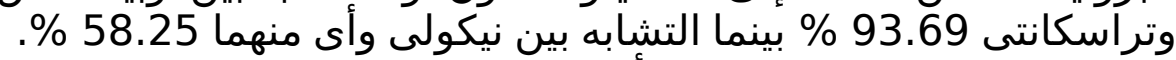

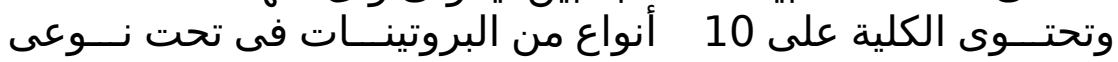

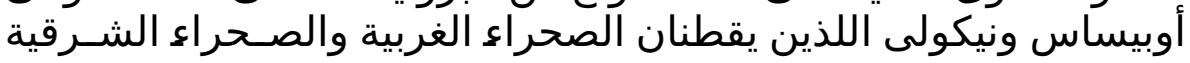

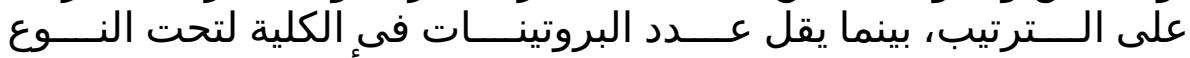

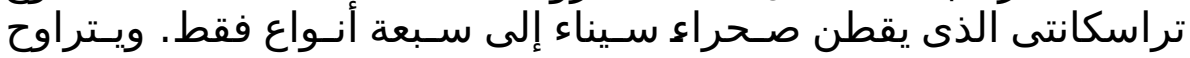

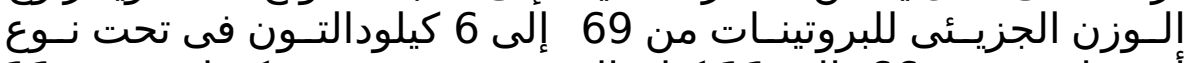

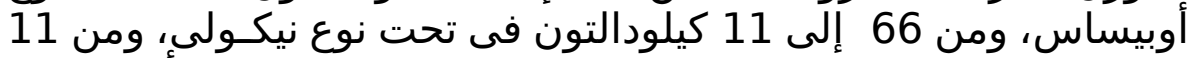

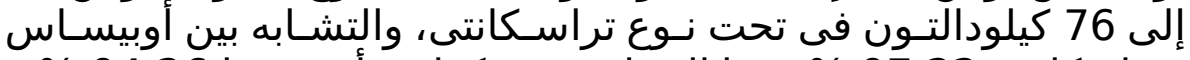

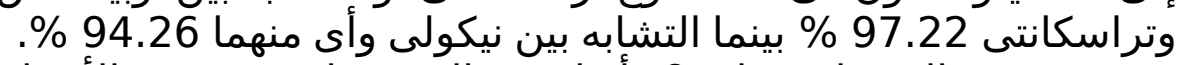

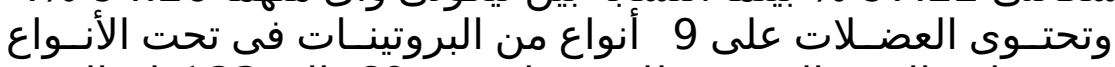

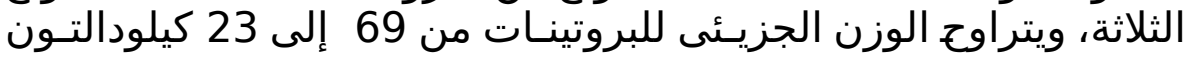

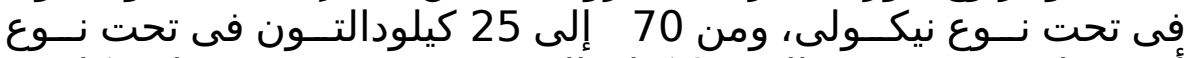

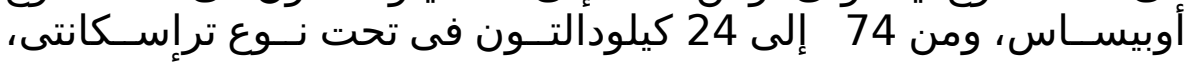


وأى منهما 94.92 \% و 94.

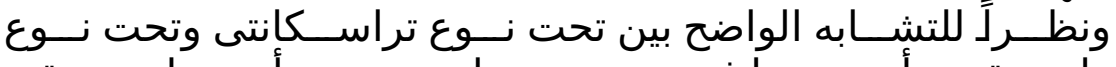

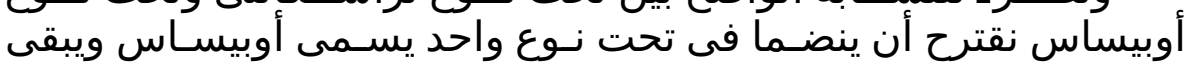

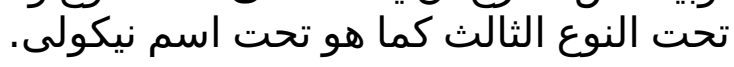

